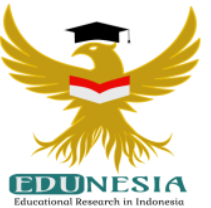

\title{
The Effect of Problem-Posing Learning Method on Students Achievement in Reading Invitation Letter
}

\author{
Mutia Nasution'; Syahroni Hasan Siregar² \\ 1,2Department of English Education, STKIP Padang Lawas, Indonesia \\ ${ }^{1}$ Corresponding Email: mutianasution238@gmail.com, Phone Number: 0852 xxxx xxxx
}

\author{
Article History: \\ Received: July 03, 2021 \\ Revised: July 08, 2021 \\ Accepted: July 10, 2021 \\ Online First: July 16, 2021
}

\section{Keywords:}

Invitation Text,

Problem-Posing Learning

Method,

Reading

Kata Kunci:

Membaca,

Metode Problem-Posing,

Teks Undangan.

How to cite:

Nasution, M., \& Siregar, S.H. (2021). The Effect of ProblemPosing Learning Method on Students Achievement in Reading Invitation Letter. Edunesia: Jurnal Ilmiah Pendidikan, 2 (3): 635-642.

This is an open access article under the $C C$-BY-NC-ND license

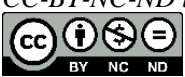

Abstract: The aims of this research is to know if there is a significant effect of problem-posing learning method on students' achievement in reading invitation text of the twelfth grade students of SMA Negeri 1 Sipirok. The population is the twelfth grade students of SMA Negeri 1 Sipirok, which is consist of 190 students. Then, the sample is taken from the population by cluster random sampling technique and the total sample is 79 students. The writer uses experimental method. After calculating the data, it is found that the mean score of students reading invitation letter before taught by Problem Posing learning method is 68; it is categorized "enough". While the mean score of students reading invitation letter after taught by Problem Posing learning method is 79, it is categorized "good". After finding the score of $t_{\text {test }}$ and $t_{\text {table, both of the scores are }}$ compared. It is found that $t_{\text {test }}$ is higher than $t_{\text {table }}\left(t_{\text {test }}>t_{\text {table }}=\right.$ $15.71>2.04)$. It means there is significant effect of Problem Posing learning method on reading invitation letter of the Twelfth grade students of SMA Negeri 1 Sipirok. So, the hypothesis in this research can be accepted.

Abstrak: Penelitian ini bertujuan untuk mengetahui apakah ada pengaruh yang signifikan antara metode pembelajaran problem posing terhadap hasil belajar siswa dalam membaca teks undangan pada siswa kelas XII SMA Negeri 1 Sipirok. Populasi dalam penelitian ini adalah siswa kelas XII SMA Negeri 1 Sipirok yang berjumlah 190 siswa. Kemudian sampel diambil dari populasi dengan tekhnik cluster random sampling dan jumlah sampel sebanyak 79 siswa. Penulis menggunakan metode eksperimen. Setelah dilakukan perhitungan data didapatkan bahwa rata-rata nilai siswa dalam membaca surat undangan sebelum diajar dengan metode Problem Posing adalah 68; dikategorikan "cukup". Sedangkan nilai rata-rata siswa membaca surat undangan setelah diajar dengan metode pembelajaran Problem Posing adalah 79, termasuk kategori "baik". Setelah didapatkan skor $t_{\text {test }}$ dan $t_{\text {tabel }}$ kedua skor tersebut dibandingkan. Diketahui bahwa $t_{\text {hitung }}$ lebih besar dari $t_{\text {tabel }}$ ( $\left.t_{\text {hitung }}>t_{\text {tabel }}=15,71>2,04\right)$. Artinya ada pengaruh signifikan antara metode pembelajaran Problem Posingterhadap kemampuan membaca surat undangan pada siswa kelas XII SMA Negeri 1 Sipirok. Sehingga dugaan jawaban dalam penelitian ini dapat diterima. 


\section{A. Introduction}

English is an international language becomes important languages which developed from time to time in the world. English is also to be one of many important subjects in school. It means that english is very important to be studied by students. It is learned from primary school until university (Kendal, 2015).

There are four basic skills in English teaching, they are listening, speaking, reading and writing. One of important skills is reading. Reading is one of the basic skills which must be competenced by students because in reading the students can get much knowledge, so that reading becomes unimportant need for many students, especially in Senior high school in comprehending text (Souzanzan \& Zamaniyan, 2014).

Reading text has many kinds in the form of descriptive, narrative, recount, news item, report, prosedure, and fuctional text. In Senior High School students learn various of reading texts. One of them is functional texts or precisely short fuctional texts (Ting et al, 2013).

Short functional text is a short text that has forms, fuction, and specific message for the reader. Short functional text has many forms such us, shoping list, greeting cards, post cards, short message service (SMS), personal letter, email, invitation, announcement, advertisement. Invitation letter is one of that studied in Senior High School and invitation is someone's asking to the other people to come or do something (Isik \& Kar, 2012).

Hao (2018) states that Education is now oriented to develop the competence of learners so that they can find their own way in the midst of a dynamic and ambiguous world. While it has been explained in the RI Law no. 20 of 2003, that: "Education is a conscious and planned effort to create an atmosphere of learning and the learning process so that students actively develop their potential to have religious spiritual strength, selfcontrol, personality, intelligence, noble character, and the skills they need. Society, nation, and state (Komarudin et al, 2015).

Therefore, the students are expected to be able to understand invitation letter so that they can know the information in the text and answer the questions based on the text. If they have known the information in the text, so that they will be easier to answer the questions (Pasaribu, 2014).

In fact, many students are difficult in understanding invitation letter. It is proved from their difficulties in answering questions. It can be seen from the average score is 70 . This score is still low and unsatisfactory because their Standard of minimum value (KKM) is 75 and when the researcher did observation in SMA Negeri 1 Sipirok in the last January until March. The researcher often asked the students about how to understand invittaion letter but they couldn't answer it well eventhough their teacher had explained about it before and when their teacher explained to them, they were not interested to listen what their teacher explained. That's why they have not understood about it until now. It was also proved by the result of the pre-test which was gotten from thetenth grade students in SMA Negeri 1 Sipirok 2018/2019 academic year.

Teacher should arrange effective activity to raise students in reading invitation letter. The teacher should be able to choose the suitable method for teaching English. If the teacher does not use the suitable method, the students will get difficulties in understanding and answering the questions continually and the KKM can not be reached.

If the method of teaching and learning process is based on necessity, the result of learning would be better and the students will get success in answering the questions because they have understood what the text was about. To repair that situation, one of the 
efforts is by adjusting the effective and conducive method as the external factor which can influence the students' achievement in a certain subject especially in reading invitation letter, such as Problem-Posing Learning Method. This methods are suitable to teach reading invitation letter. Because for understandingreading invitation letter, the students must study together about it so that they can understand reading invitation letterwell.

\section{B. Method}

The writer conducted this research at SMA Negeri 1 Sipirok. The teaching learning process at this school is active. The process of this research for three month. In this learning model, the problem is not given by the teacher but the students raise their own problem, the teacher only gives the situation and the students formulate the problem based on that situation (Suarsana et al, 2019).

To get the data and information of the research, we need a method. Siregar (2013) says, "The use of appropriate research methods to avoid speculative problem solving, and increase the objectivity in exploring knowledge." It means that the using of appropriate methodology of the research to avoid the speculative problem and to increase the objectivity to get knowledge.

In this research the writer uses experimental method. According to Sugiyono (2013) said, "Experimental research can be interpreted as a research method used to find the effect of certain treatments on others under controlled conditions." It means that experimental method is used to find out the influence of certain treatment to one another in controlled condition. According to Sugiyono (2013), the research is designed as follows:

Table 1. The Research Design

\begin{tabular}{|c|c|c|c|}
\hline $\mathrm{E}$ & $\mathrm{O}_{1}$ & $\mathrm{X}$ & $\mathrm{O}_{2}$ \\
\hline
\end{tabular}

The pattern shows:
$\mathrm{E} \quad=$ Experimental Method
$\mathrm{O}_{1} \quad=$ Pre-test Experimental Group
$\mathrm{O}_{2} \quad=$ Post-test Experimental Group
$\mathrm{X} \quad=$ Represent the Experimental Group Treatment

From the pattern, it is clear the difference between experimental and treatment groups with its steps. The writer uses experimental method because with this method the writer wants to find whether there is a significant effect of writing procedure text taught by silent demonstration method.

Population is a number of all subjects which is needed in the research. According to Siregar (2013) says, "The research population is the whole (universum) of the object of research which can be in the form of humans, animals, plants, air, symptoms, values, events, attitudes to life and so on." It means that population is a whole of object of the research such as human, animals, plants, air, value, event, and so on.

Based on the explanation above, the writer concludes that population is all the subject in a research that have certain qualities and determined by researcher. The population of this research is the Twelfth Grade students of SMA Negeri 1 Sipirok which consists of five classes and the total of populations were 190 students. It can be seen in the table below: 
Table 2. The population of the twelfth grade students of SMA Negeri 1 Sipirok

\begin{tabular}{ccccc}
\hline No & Class & Male & Female & Total \\
\hline 1 & XII IPA 1 & 20 & 20 & 40 \\
2 & XII IPA 2 & 20 & 19 & 39 \\
3 & XII IPA 3 & 18 & 20 & 38 \\
4 & XII IPS 1 & 30 & 8 & 38 \\
5 & XII IPS 2 & 20 & 15 & 35 \\
\hline \multicolumn{7}{c}{ Total } \\
\hline
\end{tabular}

The writer uses the multiple choice as the instrument to measure the students achievement in writing procedure text by applyed Problem-Posing Learning Method as an experimental group in XII IPA 1 class and without Problem-Posing Learning Method as a control group in XII IPA 2 class and the result of the test will be used as the data of this research.

\section{Result and Discussion}

\section{Results}

\section{Writing Procedure Text Ability before Taught by Silent Demonstration Method.}

Based on the result of the research, the writer found the result of students in reading invitation text which is different from both of scores. It could be seen that students are more active when the writer use Problem-Posing Learning method in teaching reading invitation text because this method make the students easy to understand and open their minds. The writer shows the specification of calculation in the table below:

The Score of mean, median and mode of Teaching reading invitation before Taught by Problem Posing Learning Method to the Twelfth Grade Students of SMA Negeri 1 Sipirok.

Table 3. The score of mean, median and mode

\begin{tabular}{clc}
\hline No & \multicolumn{1}{c}{ Items } & Score \\
\hline 1 & Mean & 68 \\
2 & Median & 65 \\
3 & Mode & 65 \\
\hline
\end{tabular}

From the calculation, it is known that the mean of students' achievement in reading invitation before taught by Problem Posing learning method is categorized "enough". From the calculation, the position of the mean score for this variable can be drawn in figure as follows: 


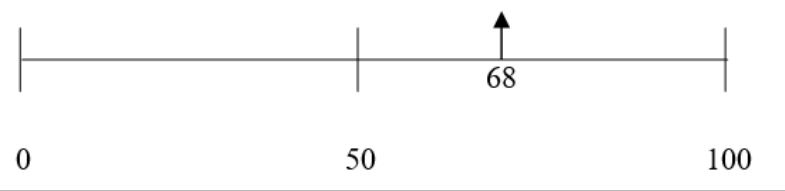

Figure 1. The position of mean score of teaching reading invitation letter before taught by problem posing learning method to the twelfth grade students of SMA Negeri 1 Sipirok.

Furthermore, the frequency distribution of writing procedure text score before taught by reading invitation method can be presented below:

Table 4. The Frequency Distribution of Teaching reading invitation Before Taught by Problem Posing Learning Method to the Twelfth Grade Students of SMA Negeri 1 Sipirok.

\begin{tabular}{ccccc}
\hline No & Interval & Frequency & $\begin{array}{c}\text { Cumulative } \\
\text { Frequency }\end{array}$ & Percentages (\%) \\
\hline 1 & $50-55$ & 2 & 2 & 5.71 \\
2 & $56-61$ & 1 & 3 & 2.86 \\
3 & $62-67$ & 18 & 21 & 51.43 \\
4 & $68-73$ & 8 & 29 & 22.86 \\
5 & $74-79$ & 2 & 31 & 5.71 \\
6 & $80-85$ & 4 & 35 & 11.43 \\
\hline & Total & 35 & - & $100 \%$ \\
\hline
\end{tabular}

From the table above it is shown that the students who get score $50-55$ are 2 students or $5.71 \%$, score $56-61$ is 1 student or $2.86 \%$, score $62-67$ are 18 students or $51.43 \%$, and score $68-73$ are 8 students or $22.86 \%$, score $74-79$ are 2 or $5.71 \%$, score $80-85$ are 4 students or $11.43 \%$.

Based on the distribution above, the writer finds that most of students score is 62-67, there are 18 students or $51.43 \%$. It is found the lowest score is 50 and the highest score is 85 . It can be seen on figure 2 as follows:

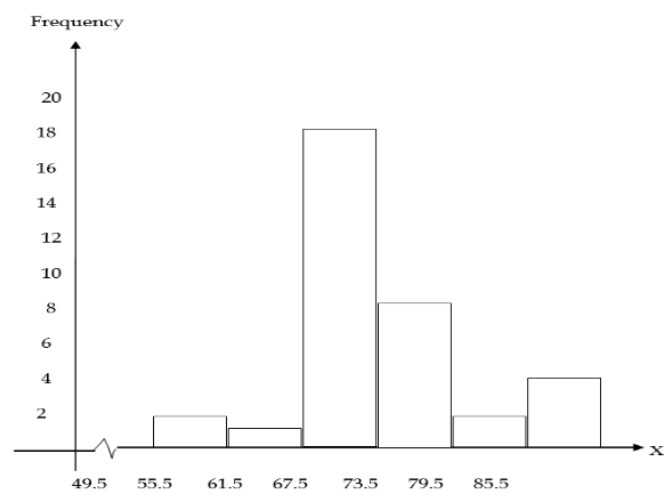

Figure 2. The histogram of teaching reading invitation letter before taught by problem posing learning method to the twelfth grade students of SMA Negeri 1 Sipirok. 
2. Writing Reading Invitation Ability After Taught by Problem Posing Learning Method

After collecting the data, it is found the highest score is 95 and the lowest score is 60 . The writer shows the specification of calculation in the table below:

Table 5. The score of mean, median and mode of teaching reading invitation letter ability after taught by problem posing learning method to the twelfth grade students of SMA Negeri 1 Sipirok.

\begin{tabular}{clc}
\hline No & \multicolumn{1}{c}{ Items } & Score \\
\hline 1 & Mean & 79 \\
2 & Median & 75 \\
3 & Mode & 75 \\
\hline
\end{tabular}

From the calculation, it is known that the mean of students' achievement in reading invitation letter ability after taught by problem posing learning method is categorized "good". From the calculation, the position of the mean score for this variable can be drawn in figure as follows:

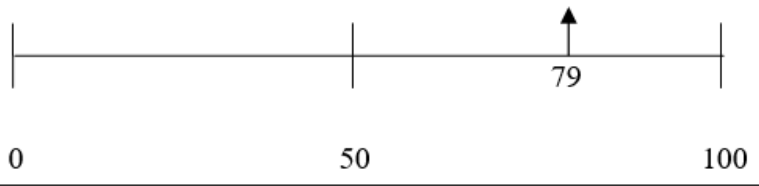

Figure 3. The position of mean score of teaching reading invitation letter before taught by problem posing learning method to the twelfth grade students of SMA Negeri 1 Sipirok

Furthermore, the frequency distribution of reading invitation letter score after taught by problem posing learning method can be presented below:

Table 6. The frequency distribution of teaching problem posing learning method to the twelfth grade students of SMA Negeri 1 Sipirok.

\begin{tabular}{ccccc}
\hline No & Interval & Frequency & $\begin{array}{c}\text { Cumulative } \\
\text { Frequency }\end{array}$ & Percentages (\%) \\
\hline 1 & $60-65$ & 2 & 2 & 5.71 \\
2 & $66-71$ & 1 & 3 & 2.86 \\
3 & $72-77$ & 15 & 18 & 42.86 \\
4 & $78-83$ & 6 & 24 & 17.14
\end{tabular}




\begin{tabular}{|c|c|c|c|c|}
\hline No & Interval & Frequency & $\begin{array}{l}\text { Cumulative } \\
\text { Frequency }\end{array}$ & Percentages (\%) \\
\hline 5 & $84-89$ & 7 & 31 & 20 \\
\hline 6 & $90-95$ & 4 & 35 & 11.43 \\
\hline \multicolumn{2}{|c|}{ Total } & 35 & - & $100 \%$ \\
\hline
\end{tabular}

Based on the distribution above, the writer finds that most of students score is 72-77, there are 15 students or $42.86 \%$. It is found the lowest score is 60 and the highest score is 95 . It can be seen on figure 4 as follows:

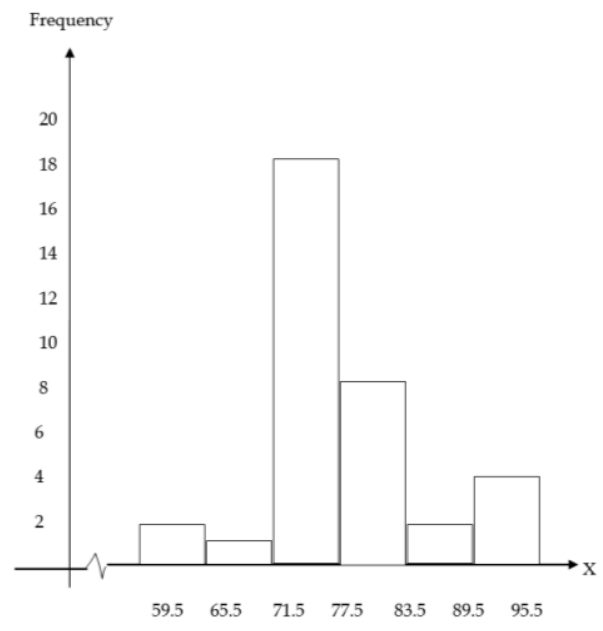

Figure 4. The histogram of teaching reading invitation letter before taught by problem posing learning method to the twelfth grade students of SMA Negeri 1 Sipirok.

\section{Discussions}

Based on the previous conclusions, it can be said that problem-posing learning method is different with other methods on students' achievement in reading explanation text. That is why the suitable method is important. It is expected that teacher should know the use of suitable method in learning process, especially in reading explanation text. In this case, it can be seen that the result of the students' achievement in reading explanation text taught by using problem-posing learning method is better than the result of the students' achievement in reading explanation text taught without using problem-posing learning method. So, for the next time, the teacher should be applied problem-posing learning method in teaching explanation text.

Teaching method will help teacher to deliver the lesson to the student. The suitable teaching method will make learning process run well so the student got information well. The teacher tries to find out the students' difficulties in learning process and motivate the student to get interest in reading explanation text so that their achievement in reading explanation text can improve.

The writer hopes this research will help and the teacher get interest to determine the suitable method in teaching explanation text because teaching method cannot separate from education or learning process. The suitable method will make the learning process successes. 


\section{Conclusion}

Based on the result of the research and data analysis, the scores of the students 'achievement by using Problem-Posing Learning Method was higher than without using Problem-PosingLearning Method. The writer concluded that there is a significant effect of Problem-Posing Learning method on students' achievement in reading explanation text at the twelfth grade students of SMA Negeri 1 Sipirok in 2018/2019 academic year.

\section{References}

Hao, W., \& Gyöngyvér, M. (2018). Interactive Problem Solving: Assessment and Relations to Combinatorial and Inductive Reasoning. Journal of Psychological and Educational Research, Vol. 26, Iss. 1, (May 2018): 90-105.

Isik, C., \& Kar, T. (2012). The analysis of the problems posed by the pre-service teachers about equations. Australian Journal of Teacher Education (Online), 37(9), 93-113.

Kendal, S. (2015). How to Write a Research Paper. UK: Bookbon.

Komarudin., Sukardjo, M., \& Ukim. (2015). Educational Foundation Concepts and Their Applications. Jakarta: PT Raja Grafindo Persada.

Pasaribu, S. (2014). The Effect of Think Pair Shair Method toward Reading Recount Text Ability (A Study at the Eighth Grade Students of SMP Negeri 1 Sipirok). Padangsidimpuan: STKIP Tapanuli Selatan Padangsidimpuan.

Souzanzan, R., \& Zamaniyan, M. (2014). The Relationship Between the Location Of The Topic Sentence And The Comprehension Of A Passage By Iranian Advanced Efl Learners. Modern Journal of Language Teaching Methods, 4(2), 237.

Siregar, S. (2014). Metode Penelitian Kuantitatif. Jakarta: Kencana Prenada Group.

Suarsana, I., Lestari, I. A. P. D., \& Mertasari, N. M. S. (2019). The Effect of Online Problem Posing on Students' Problem-Solving Ability in Mathematics. International Journal of Instruction, 12(1), 809-820.

Sugiyono. (2013). Metode Penelitian Kuantitatif, Kualitatif, dan RED. Bandung: CV. Alfabeta.

Ting, S. H., Campbell, Y. M., Law, L., \& Poh, H. H. (2013). Explanations without a purpose? Genre-based instruction and academic writing. Journal of Academic Language and Learning, 7(1), A26-A39. 